\title{
Research on the Development of Rural Tourism in Linyi City
}

\author{
Xue-zhi Li \\ School of Business, Linyi University, Linyi, Shandong, China
}

\begin{abstract}
Rural tourism is a rapidly developing tourism project in Linyi city. Due to the late start of China's rural tourism, rural tourism product development process is not very perfect. With the "building a new socialist countryside" strategy, rural tourism is given a more far-reaching social and economic significance. This paper analyzes the current development of rural tourism including the development opportunity and current situation,at the same time Put forward the problems and measures to improve the rural tourism development in Linyi City.
\end{abstract}

Keywords_-Rural tourism development; Strategy; Linyi city

\section{临沂市乡村旅游发展探讨}

\author{
李学芝 \\ 临沂大学商学院, 临沂, 山东, 中国
}

摘 要 近年来临沂市乡村旅游项目发展迅速, 但临沂市乡村旅游起步较晚, 存在很多不完善的地方。本文分析了临沂市乡村旅 游发展的契机及现状，提出了发展过程中存在的问题，并探讨了在“社会主义新农村建设”的社会背景下发展临沂市乡村旅游的措施。

关键词乡村旅游发展, 措施, 临沂市

\section{1. 乡村旅游的含义}

西班牙旅游学术界将乡村旅游分为传统乡村旅游和现 代乡村旅游。传统的乡村旅游出现在工业革命以后, 主要 来源于一些来自农村的城市居民以“回老家”度假的形式出 现。而现代乡村旅游是在 20 世纪 80 年代出现在农村区域 的一种新型的旅游模式, 旅游者的旅游动机明显区别于回 老家的传统旅游者。

国内有关乡村旅游的定义较多: 何景明和李立华认为 狭义的乡村旅游是指在乡村地区, 以具有乡村性的自然和 人文客体为旅游吸引物的旅游活动。乡村旅游的概念包含 了两个方面: 一是发生在乡村地区, 二是以乡村性作为旅 游吸引物, 二者缺一不可。

2004 年在贵州举行的乡村旅游国际论坛上, 与会的专 家们最终形成了一个比较统一的意见, 他们认为中国的乡 村旅游至少应包含以下三点: 一是以独具特色的乡村民俗 民族文化为灵魂, 以此提高乡村旅游的品位和丰富性 ; 二 是以农民为经营主体，充分体现“住农家屋、吃农家饭、干 农家活、享农家乐”的民俗特色; 三是乡村旅游的目标市场
应主要定位为城市居民，满足都市人享受田园风光、回归 淳朴民俗的愿望。

\section{2. 临沂市乡村旅游发展的基础}

临沂位于山东省东南部, 地近黄海, 南邻苏北。现辖 9 县 3 区和 3 个开发区, 157 个乡镇、街道, 7167 个行政 村 (居), 1081 万人, 总面积 1.72 万平方公里, 平原、山 区、丘陵各占三分之一, 是山东省人口最多、面积最大的 市。近年来, 临沂市成功创建了全国文明城市、全国双拥 模范城市、中国优秀旅游城市、国家园林城市、国家环保 模范城市、国家卫生城市, 被授予中国书法名城、中国地 热城、中国市场名城、中国物流之都称号。

\section{1 临沂市乡村旅游发展契机}

\subsection{1 时代需求}

据临沂市统计局资料, 2014 年临沂城镇居民人均可支 配收入 3.03 万元, 农民人均纯收入 1.16 万元, 分别增长 $10.3 \%$ 和 $11.9 \%$, 农村居民收入增速连续 5 年快于城镇。经 
济的繁荣，带给了人类丰富的物资享受，同时越来越多的 人渴望体验乡村生活。这种现象在人口聚集最紧密的的兰 山区需求越来越大, 由于紧张劳累的都市生活, 使城市居 民生活节奏加快, 人很难得到清闲与安逸, 因此, 能带给 人们身体放松、心灵休㮩的以乡村为背景的旅游产品就顺 应而生了。

\subsection{2 红色旅游助推乡村旅游发展}

习近平总书记视察山东时候用 “水乳交融、生死与共” 来评价沂蒙精神, 临沂市“沂蒙故乡”。发展红色旅游是纪 念革命先烈、缅怀伟人丰功伟绩、感受革命精神的重要方 式, 是新时期进行爱国主义教育和思想政治教育, 凝聚人 心, 建设和谐社会的需要。近年来临沂市将 “红色风情” 作 为旅游发展的四大主题之一, 加大了投资力度, 而这些红 色旅游景区基本上位于临沂市的乡村地域, 红绿结合, 极 大地推动了临沂市乡村旅游的发展。

\section{1 .3 新农村建设的需要}

近年来, 临沂市乡村旅游蓬勃发展, 乡村旅游已成为 现代旅游业新的成长点, 成为带动农村脱贫致富的亮点。 以蒙山云蒙景区为例, 围绕景区发展了农家乐旅游接待村 56 个，经营户 260 余家，2013 年“十一”黄金周期间接待游 客 13 余万人次, 实现经营收入 2400 余万元; 沂南县竹泉 村将旅游开发与新农村建设相结合, 将农民群众整体搬迁 进新村居住, 从事旅游服务, 人均收入大幅提升; 沂水县 院东头镇依托天然地下画廊等景区, 培育了 50 余个休闲度 假特色村，近千名农民从中受益。

乡村旅游既是乡村发展的新途径, 也是旅游业发展的 新领域, 使得乡村同时获得三大效益, 即社会效益, 经济 效益和环境效益。在“新农村、新旅游、新体验、新风尚” 思路的引领下, 稳固及加强乡村旅游, 振兴乡村旅游, 繁 荣农村、富裕农民是临沂市新农村建设的重要任务。乡村 的发展、乡村景观建设、乡村遗产保护等问题在新农村建 设中也已引起广泛的关注, 因此发展乡村旅游与乡村景观 保护也是新农村建设需要关注的问题。

\section{2 临沂市乡村旅游资源丰富}

截至 2014 年, 临沂全市拥有全国休闲农业与乡村旅游 示范县 1 个、示范点 2 处、国家级农业旅游示范点 7 个; 省级旅游强县 6 个、强乡镇 15 个、特色景观旅游名镇 2 个、 特色村 15 个、农业旅游示范点 23 个、休闲渔业示范点 3 个; 全市现有农家乐经营户 1100 家, 从业人员达到 1.1 万 人。2013 年全市乡村旅游接待游客 1710 万人次, 实现收 入 144 亿元。

\subsection{1 采摘果木园林资源}

临沂市果木园林比较集中的如费县的万亩梨园, 郯城 县的万亩板栗园和万亩银杏园, 蒙阴县百里果乡园, 莒南 县的洙边镇的万亩板栗园、茶园和厉家寨大樱桃园, 每年 都吸引大批游客前来观光旅游采摘,

\section{2 .2 高新技术示范园区}

高新技术示范园区主要国内外种植高新技术和品种, 使园区内的果木、花卉、蔬菜等植物即有食用价值, 又有 观赏价值。比较有代表性的是沂南县大地乡村科技示范园, 罗庄区飞龙花卉等, 还有近年比较受市场欢迎的多肉植物 经营园区--汶河多肉基地。

\subsection{3 “农家乐”}

在旅行逐渐成为一种文化生活而快速发展的大背景 下, 以“进农家院、吃农家饭、喝农家酒、饮农家茶、住农 家房、享农家乐”为特色的“农家乐”休闲旅行正日益受到国 内外旅行人士的欢迎及其认同。近几年来，“农家乐”休闲 旅行从无到有, 发展初具规模, 正逐渐构成自我的特点, 成为繁荣经济、转移农村劳动力、增进农民增收的又一大 重要载体。临沂市农家乐在临沂开展比较成功的有沂南县 铜井镇红石寨旅游度假区、兰山区云瀑洞天景区、孟良固 战役遗址景区, 还有蒙阴蒙山大方之家, 临沂“农家乐”休 闲旅行现已发展成熟, 并构成了自我的特色。

\section{3.临沂市乡村旅游发展面临的问题}

\section{1 品种形式单一}

目前临沂市乡村旅游开发多集中在采摘农业、休闲农 业等旅游产品上, 而对乡村文化传统和民风民俗资源的开 发重视不够, 同时由于旅游产品缺乏知识性和趣味性, 乡 村旅游产品雷同多, 缺少特色产品。

\section{2 乡村旅游从业人员素质需要提高}

乡村旅游经营者多数是村民、市场竞争意识淡薄、经营 理念缺乏、相关专业知识、业务技能和管理经验能力不足, 对服务质量及服务水平重视程度不够, 不能满足旅游者需 求, 并且主动宣传和参加集体促销的意识和要求不强, 这 很难适应旅游市场竞争的形式。

\section{3 乡村旅游环境有待改善}

乡村旅游业态经营单位的餐饮、住宿、娱乐、购物、 停车场的卫生水平急需提升: 游览娱乐场地脏乱、餐饮加 工和就餐环境不卫生、住宿场所卫生设施和环境不整洁、 
旅游则所简随脏臭、停车场所坑坑洼洼、购物场所灰尘较 多以及景点内垃圾乱丢弃、污水乱排放、家禽家畜乱排便 等影响环境卫生的问题都有待相关部门解决改善。部分“农 家乐“餐饮单位尤其是家庭共用厨房的小型“农家乐”的功 能布局不合理，工艺过程有交叉，功能间缺少，卫生设施 设备不全，易造成交叉污染。同时，部分经营户为体现“农 家乐”家常便饭的意图, 在食品操作加工上采用不卫生的 “土方法“，也给食品卫生安全带来不少隐患。

\section{4.临沂市发展乡村旅游的措施}

4.1 贯彻乡村旅游规划, 丰富乡村旅游产品

近年来临沂市编制了多部区域性乡村旅游规划, 在进 行乡村旅游开发时必须贯彻这些规划。这样才不会破坏原 有的自然生态环境和浓郁特色的乡土人文环境。

乡村旅游餐饮业方面, 挖掘临沂菜内涵, 发展特色餐 饮, 打造餐饮品牌。建设有特色、有民俗风情的美食街, 发展特色农家乐、土菜馆等。

临旅游住宿业方面, 让“民居旅馆”更有特色。民居旅 馆是乡村旅游的一个重要载体, 价格低廉、富于特色, 在 直接增加了当地居民收入的前提下又给旅游者提供了一次 对所到之地风土人情的真切体验。

重视旅游商品开发, 扶持旅游商品生产企业发展, 支 持临沂市经济开发区内旅游商品产业园区和区县旅游商品 生产基地建设。突出地方特色, 赋予旅游商品沂蒙文化内 涵, 强化“名牌”战略, 拓宽营销渠道, 完善市场机制, 营 造良好的购物环境。旅游产业要以发展文化娱乐增加内涵” 的要求, 加快娱乐设施建设, 策划开发休闲、健身、娱乐、 消遣、演艺、影视等旅游娱乐产品, 促进文化与旅游深度 结合。

\section{2 培训乡村旅游从业人员, 提高乡村旅游服务的质量}

临沂市和有条件的县(市、区)人民政府应当重视和支 持旅游院校及学科建设, 发展旅游职业教育, 加强旅游科 学研究, 培养旅游专业人才。加快实施乡村旅游培训工 程, 在全市开展旅游培训下乡活动, 抽调涉旅院校教师组 成讲师团, 以培训乡村旅游实用人才为目的, 以讲授示范 实用技术为主要内容, 围绕乡村旅游接待标准、食品安全
控制与环境卫生、餐饮服务与管理、客房服务与管理、服 务礼仪、鲁菜制作等重点, 开展基本培训, 尽快锻炼一批 懂乡村旅游、善指导的基层干部, 培养一批懂经营、善管 理的乡村旅游经营业主, 培训一批懂规范、善服务的乡村 旅游从业人员。

\section{3 改善乡村旅游环境, 打造临沂市乡村旅游特色品牌}

政府方面，为推动“改则改㕑”，山东省旅游局制定了 《山东省乡村旅游经营业户“改则改㕑”奖励办法》。2014 年上半年在临沂市开展了乡村旅游经营业户“改则改劂”工 作，已经大大改善了乡村旅游经营的状况。

品牌方面, 临沂将突出生态、红色、亲情旅游资源优 势, 全力打造“好客沂蒙人家”乡村旅游品牌, 以品牌营销为 重点, 实现全市乡村旅游统一标准、统一形象、统一宣 传、统一营销。在 “好客沂蒙人家” 品牌建设过程中, 积极培 育一批特色餐饮、乡村度假、乡村游乐、乡土购物等特色 乡村游产品, 树立乡村旅游服务典型, 努力实现临沂乡村旅 游新一轮跨越式发展。

\section{参考文献(References)}

[1] He Jingming, Li Lihua. Study on the concept of "rural tourism". Journal of Southwestern Normal University (HUMANITIES AND SOCIAL SCIENCES EDITION), 2002, 28 (5):125-128.

[2] Guang Wei. Environmental protection and economic sustainable development in rural tourism development. The research of agricultural modernization, 2000, (5).

[3] Pan xinhua, Liu Pingan. Approach to development of Yanan tourist industry. The reform andstrategy, 2005, (138): 28.

[4] Wu, Cai Yunlong, Jin Bo. The objectives, characteristics and products of rural tourism. Journal of Beijing Forestry University,.2002.24 (3): 78-82.

[5] Wang Yanli. Thinking of rural industrial structure adjustment of China. Qiqihar University,.2003(3): 33-35.

[6] Fan Chun. On the development of rural tourism. Journal of Yuzhou University (Social Science Edition). 2002.19(5): 20-23.

[7] Guo Huancheng, Xu Huilin. Principles and methods of rural tourism planning. Science Press,.2006:2- 5. 